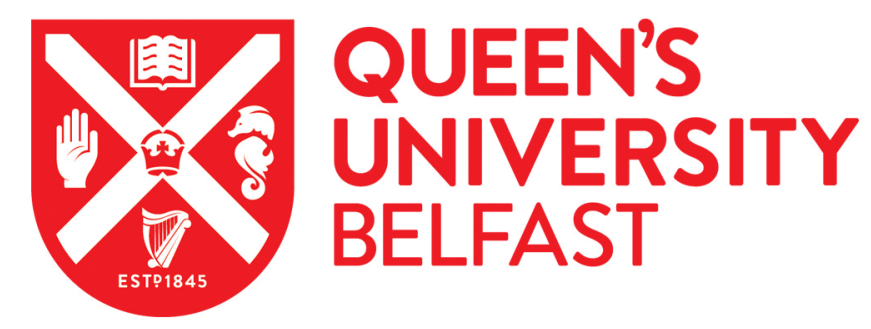

\title{
Women lawyers and the struggle for change in conflict and transition
}

Bryson, A., \& McEvoy, K. (2016). Women lawyers and the struggle for change in conflict and transition. Australian Feminist Law Journal, 42(1), 51-73. https://doi.org/10.1080/13200968.2016.1181035

\author{
Published in: \\ Australian Feminist Law Journal
}

\section{Document Version:}

Peer reviewed version

Queen's University Belfast - Research Portal:

Link to publication record in Queen's University Belfast Research Portal

\section{Publisher rights}

Copyright 2016 Taylor \& Francis.

This work is made available online in accordance with the publisher's policies. Please refer to any applicable terms of use of the publisher.

\section{General rights}

Copyright for the publications made accessible via the Queen's University Belfast Research Portal is retained by the author(s) and / or other copyright owners and it is a condition of accessing these publications that users recognise and abide by the legal requirements associated with these rights.

Take down policy

The Research Portal is Queen's institutional repository that provides access to Queen's research output. Every effort has been made to ensure that content in the Research Portal does not infringe any person's rights, or applicable UK laws. If you discover content in the Research Portal that you believe breaches copyright or violates any law, please contact openaccess@qub.ac.uk. 


\title{
Published in Australian Feminist Law Journal Vol. 42 (1) 2016
}

\section{Women Lawyers and the Struggle for Change in Conflict and Transition}

\author{
Anna Bryson and Kieran McEvoy ${ }^{1}$
}

\begin{abstract}
This article examines the particular experiences of female 'cause lawyers' in conflicted and transitional societies. Drawn from an ongoing comparative project which involved fieldwork in Cambodia, Chile, Israel, Palestine, Tunisia and South Africa, the paper looks at opportunities, obstacles and the obduracy required from such lawyers to 'make a difference' in these challenging contexts. Drawing upon the theoretical literature on the sociology of the legal profession, cause-lawyers, gender and transitional justice, and the structurelagency nexus, the article considers in turn the conflict $\backslash$ causelawyering intersection and the work of cause-lawyers in transitional contexts. It concludes by arguing that the case-study of cause-lawyers offers a rebuttal to the charge that transitional justice is just like 'ordinary justice'. It also contends that, notwithstanding the durability of patriarchal power in transitional contexts, law remains a site of struggle, not acquiescence, and many of these cause-lawyers have and continue to exercise both agency and responsibility in 'taking on' that power.
\end{abstract}

\subsection{Introduction}

[I]t was tough. I think it was tough for men and women because, you know, we were fighting a system where the prosecutors or the presiding officers, everybody was hostile ... It was a hard long fight right through. But being a woman obviously makes it even more difficult, you know. ${ }^{2}$

There aren't a lot of women in, you know, in high ranking positions in the Bar Association ... And of course there's the organisational culture that comes with that what is important, how you measure success, who is influential and how you become

\footnotetext{
* Dr Anna Bryson is a Research Fellow at the School of Law, Queen's University Belfast. Her research interests span the fields of oral history and transitional justice. Her most recent publications focus on the role of oral archives in giving voice to victims and dealing with the past. a.bryson@qub.ac.uk. Kieran McEvoy is Professor of Law and Transitional Justice at the School of Law, Queen's University Belfast and a Senior Research Fellow at the Senator George J. Mitchell Institute for Global Peace, Security and Justice. He has conducted research in over a dozen conflicted or transitional countries on topics including politically motivated prisoners, ex-combatants, victims, amnesties, truth recovery, human rights, restorative justice and the role of lawyers in conflict and transition. k.mcevoy@qub.ac.uk. The authors would like to acknowledge the Economic and Social Research Council (ESRC) which funded this research (Grant Reference ES/J009849/1), the anonymous reviewers and our colleagues on the project, Professor Louise Mallinder and Marny Requa. In addition, we would also like to thank those who gave useful feedback on previous versions of this paper presented at the Socio-Legal Studies Association in Warwick and the Law and Society Conference in Seattle in 2015.

2 Personal interview with veteran struggle lawyer, Cape Town, South Africa, 12 August 2014.
} 
influential ... from the very beginning it's very masculine, it's a very masculine profession. $^{3}$

The study of transitional justice is already replete with analysis of the legal work and effect of various international and domestic courts and tribunals, amnesties, truth commissions and rule of law programmes. ${ }^{4}$ The 'rule of law' is widely accepted as perhaps the key material and symbolic marker that denotes the break with the past in transitional societies. ${ }^{5}$ While there is a significant literature on judicial appointments, independence and decision making in transitional contexts, ${ }^{6}$ the role of lawyers as social, political and moral actors outside the courts, or indeed as the 'real people at work in the system ${ }^{7}$ is much less developed. It is true that anthropologically influenced work on legal pluralism, post-colonial lawyering and transitional justice 'from below' does explore contests over the ownership of justice and the dominance of lawyers. ${ }^{8}$ Indeed interdisciplinary critiques of excessive legalism are becoming increasingly common in the field. ${ }^{9}$ While some scholars have examined the challenges of lawyering in conflicted and transitional societies, ${ }^{10}$ such studies usually focus on

\footnotetext{
${ }^{3}$ Personal interview with human rights lawyer and activist, Tel Aviv, Israel, 14 May 2014.

${ }^{4}$ Schabas William A and Bernaz Nadia Routledge Handbook of International Criminal Law Routledge Abingdon 2011; Mallinder Louise Amnesty, Human Rights and Political Transitions: Bridging the Peace and Justice Divide Hart Publishing Oxford 2008; Chapman Audrey R and Van der Merwe Hugo (eds) Truth and Reconciliation in South Africa: Did the TRC Deliver? University of Pennsylvania Press Philadelphia 2009.
}

${ }^{5}$ Teitel Ruti Transitional Justice Oxford University Press Oxford 2000; Czarnota Adam, Krygier Martin and Sadurski Wojciech (eds) Rethinking the Rule of Law After Communism Central European University Press Budapest 2006; Couso Javier, Huneeus Alexandra and Sieder Raches (eds) Cultures of Legality: Judicialization and Political Activism in Latin America Cambridge University Press Cambridge 2010.

${ }^{6}$ See for example Morison John, McEvoy Kieran and Anthony Gordon (eds) Judges, Transition and Human Rights Oxford University Press Oxford 2007; Hilbrink Lisa Judges Beyond Politics in Democracy and Dictatorship: Lessons from Chile Cambridge University Press Cambridge 2007.

7 Friedman Lawrence The Legal System: A Social Science Perspective Russell Sage New York 1975 p 155.

${ }^{8}$ Engle Merry Sally Human Rights and Gender Violence: Translating International Law into Local Justice University of Chicago Press Chicago 2005; Sharafi Mitra 'A New History of Colonial Lawyering: Lihowski and Legal Identities' (2007) 32(4) Law and Social Inquiry 1059; McEvoy Kieran 'Beyond Legalism: Towards a Thicker Understanding of Transitional Justice' (2007) 34(4) Journal of Law and Society 411.

${ }^{9}$ See for example McEvoy Kieran and McGregor Lorna (eds) Transitional Justice from Below: Grassroots Activism and the Struggle for Social Change Hart Publishing Oxford 2008; Clark Phil The Gacaca Courts, Post-Genocide Justice and Reconciliation in Rwanda Cambridge University Press Cambridge 2010; Palmer Nicola Courts in Conflict: Interpreting the Layers of Justice in Post-Genocide Rwanda Oxford University Press Oxford 2015.

${ }^{10}$ Abel Richard L Politics by Other Means: Law and the Struggle Against Apartheid in South Africa 1980-1994 Routledge London 1995; Caiger Andrew Cause Lawyering in South Africa: The Process of Empowering a Rights Based Legal Culture and its Socio-Political Impact Austin \& Winfield Publishers San Francisco 2005; Dezalay Yves and Garth Bryant G The Internationalization of Palace Wars: Lawyers, Economists and the Contest to Transform Latin American States University of Chicago Press Chicago 2002; Hajjar Lisa Courting Conflict: The Israeli Military Court System in the West Bank and Gaza University of California Press Santa 
one case study, and correspondingly few examine the particular role of female lawyers in such contexts.

This article is drawn from a large comparative study of lawyers in six jurisdictions, namely Cambodia, Chile, Israel, Palestine, Tunisia and South Africa. ${ }^{11}$ In 2014 we conducted a total of 40 semi-structured interviews with women lawyers and activists (from a total of over 120 interviews spread across the jurisdictions). Although our questions on gender were addressed to both male and female interviewees the quotes cited in this article are exclusively drawn from interviews with women. ${ }^{12}$ The jurisdictions were chosen in order that we might do 'structured, focused comparisons ${ }^{\prime 13}$ drawing on semi-structured interviews with key actors in order to provide a balance that allows for a nuanced grasp of the local and the potential for cautious ' mid-range theorising' ${ }^{14}$ The case-studies were specifically chosen to capture different dynamics which interested us: (a) countries with a history of violence and/or oppression at different stages of transition; (b) jurisdictions from the principal 'legal families' 15 (i.e. the Common Law tradition, the Civil Law Tradition, Islamic tradition, as well as Asian and African legal tradition); and (c) jurisdictions which variously had experience of cause or struggle lawyering, international justice, and past focused transitional justice. As evidenced by the quotes above, the focus of the interviews was both on the material areas of struggle in which the interviewees were engaged and also their experiences as women lawyers working in what were often viewed as patriarchal legal cultures.

Monica 2005; Collins Cath Post-transitional Justice: Human Rights Trials in Chile and El Salvador Pennsylvania State University Press University Park 2010.

${ }^{11}$ As noted above, this major international comparative research project is funded by the Economic and Social Research Council (ES/J009849/1). See www.lawyersconflictandtransition.org (last visited 8 January 2016).

${ }^{12}$ In Cambodia due to ongoing concerns regarding both personal safety and professional life each of the three women we interviewed asked to be referred to simply as 'an international lawyer'. In Chile we spoke to a government lawyer, the director of a human rights organisation, a legal academic and human rights activist, a lawyer in private practice and a civil society activist. Our cohort in Israel included three legal academics and human rights activists, a politician and lawyer, three lawyers working in human rights NGOs and two lawyers working in private practice. In Palestine the women we interviewed included three female lawyers employed by human rights NGOs, a lawyer in private practice and a civil society activist. In Tunisia female interviewees included one of Ben Ali's former lawyers and allies, two Europeans working for Tunisian based NGOs, three 'cause lawyers' working in private practice, and two lawyers working for human rights NGOs. Finally in South Africa we interviewed two celebrated female cause lawyers, a legal academic and activist, and a former ANC activist.

${ }^{13}$ Zartman I William 'Comparative Case Studies' (2005) 10 International Negotiation 3 at 7.

${ }^{14}$ Merton Robert On Theoretical Sociology Free Press New York 1968.

${ }^{15}$ Glenn H Patrick 'Comparative Legal Families and Comparative Legal Traditions' in Reimann Mathias and Zimmermann Reinhard (eds) The Oxford Handbook of Comparative Law Oxford University Press Oxford 2006 p 421-440. 
For the current paper, we seek to explore issues which illuminate the struggles of women lawyers in such settings while still acknowledging the very real distinctions both between the lawyers themselves and between case-studies at varying stages of conflict and transition. As Meintjies et al have argued, 'women who live through war and conflict do not fall into a single group' ${ }^{16}$ To seek to present the experiences of women lawyers as 'the same' in one jurisdiction, never mind six, would fall into the well identified trap of essentialising the lives of women in transitional justice while getting on with the 'serious business' of discussing the lives of men in all of their intricacies and complexities. ${ }^{17}$ As is discussed below, there are important ways in which gender intersects with variables such as race, class and religion, and of course the local context in which these women lawyers work directly impacts upon their professional and personal lives. With regard to the latter, each jurisdiction has its own unique historical, cultural, religious and political variables, as well as different legal cultures. For example, in Chile, one cannot but acknowledge the very specific influence of the Catholic Church in shaping both approaches to dealing with the past and related issues concerning the cause of female equality. In South Africa, the particular prominence of some women in the struggle (with many straddling the ranks of struggle lawyers and the women's movement) is sometimes evidenced to eulogise the advances in women's civil and political rights in transition - an assumption which we question. ${ }^{18}$ In a somewhat analogous fashion, the experiences of women cause-lawyers in Israel and Palestine must be framed within the broader reality of the ongoing occupation and associated conflict. Central to our approach to comparative research is to 'make sense of difference'. ${ }^{19}$ While fore-grounding important distinctions between the lawyers we interviewed and the local variables across all of the case-studies, we seek to draw out key themes which allow us the opportunity to develop what Popper referred to as 'contingent empirical generalisations', ${ }^{20}$ i.e. contingent because they apply usually under certain (specified) conditions, and empirical because they are derived from close analyses of a range of historical cases.

It might be useful at this stage to offer a brief overview of some of the key concepts which inform the discussions in this paper. In particular we draw on some of the most

\footnotetext{
${ }^{16}$ Meintjies Sheila, Pillay Anu and Turshen Meredeth (eds) The Aftermath: Women in Post-Conflict Transformation Zed Books London 2001 p 16.

${ }^{17}$ Alam Mayesha Women and Transitional Justice Palgrave London 2004 p 3.

${ }^{18}$ Hassim notes, for example, that ' $[t]$ he transition to democracy in South Africa ushered in a formal institutional framework and a government that has been held up as a model of serious commitment to the ideal of gender equality.' Hassim Shireen 'The Gender Pact and Democratic Consolidation: Institutionalizing Gender Equality in the South African State' (2003) Feminist Studies 29(3) 505 at 505. See further Waylen Georgina Engendering Transitions: Women's Mobilizations, Institutions and Gender Outcomes Oxford University Press Oxford 2007 pp 199-202.

${ }^{19}$ Nelken David Comparative Criminal Justice: Making Sense of Difference Sage Publications London 2010. ${ }^{20}$ Popper Karl The Logic of Scientific Discovery Routledge London 1959.
} 
relevant literature on cause lawyers, gender and the legal profession, gender in transitional justice and the structure agency nexus.

In all of the societies we have been researching law has been used as a tool of repression by the state and, to varying degrees, as one source of resistance by those engaged in political and social struggles for change. Inevitably in such contexts, the role of lawyers becomes crucial, whether as detached professionals 'delivering a service' to their clients or as self-conscious political actors who use 'legal skills to pursue ends and ideals that transcend client service' within and beyond the court as part of such broader struggles. ${ }^{21}$ 'Cause-lawyering' is the genre of scholarship most associated with analysing such lawyers. Sarat and Scheingold have edited a number of important US based and international collections detailing the ways in which causelawyers contest prevailing political, social, moral or legal power. While there are multiple definitions, at its core cause lawyering is a form of 'moral activism' which transcends the boundaries between the legal and the political, wherein committed lawyers 'do more' than simply deploy their technical services on behalf of their client. 22 Such lawyers may engage in both pro bono and paid work, strategic litigation, develop networks and relationships, or indeed become part of broader social or political movements and view their responsibilities as going well beyond the court room or lawyers office to argue and mobilise publicly for the 'cause.' ${ }^{23}$ Cause lawyers are essentially much more comfortable than conventional lawyers with the view that the law and lawyering is quintessentially political.

Within the broader sociology of the legal profession from which the cause-lawyering literature emerges, there is not surprisingly a significant focus on gender. A range of scholar-activists have well captured the close interrelationship between feminist law reform and the gendered structure of the legal profession. ${ }^{24}$ For example, MenkelMeadow has argued that the 'story' of women's entry to the legal profession is, for most nations, an 'easy one to tell': university education expanded exponentially in the 1970s, many of the most significant formal barriers to women entering the profession were lifted and, in tandem with wider cultural developments and changing societal attitudes towards women's roles in family and professional life, women did make

\footnotetext{
${ }^{21}$ Sarat Austin and Scheingold Stuart A Something to Believe In: Politics, Professionalism and CauseLawyering Stanford University Press Palo Alto 2004 pp 3-4.

22 Boukalas Christos 'Politics as Legal Action / Lawyers as Political Actors: Towards a Reconceptualisation of Cause Lawyering' (2013) 22(3) Social \& Legal Studies 395.

${ }^{23}$ Devyani Prabhat 'After 9/11: Guantánamo And The Mobilization Of Lawyers' (2011) 54 Studies in Law, Politics, and Society 213; Garcia Melanie 'The Lawyer as Gatekeeper: Ethical Guidelines for Representing a Client with a Social Change Agenda' (2011) 24 Georgetown Journal of Legal Ethics 551.

${ }^{24}$ Prominent scholar-activists include Catharine MacKinnon, Ruth Bader Ginsburg, Martha Fineman, Mari Matsuda and Frances Webber. See Grant Bowman Cynthia and Schneider Elizabeth M 'Feminist Legal Theory, Feminist Lawmaking, and the Legal Profession' (1998) 67(2) Fordham Law Review 249; Scales Ann Legal Feminism: Activism, Lawyering, and Legal Theory New York University Press New York 2006.
} 
advances in the legal profession. ${ }^{25}$ However, despite women now constituting over half of law school entrants in many settled democracies, numerous analyses have charted that informal barriers to advancement (as reflected in earnings, career progression, and status), still persist. Further markers of inequality include the concentration of women in silos of 'gendered legal work' (e.g. over-representation in government, public interest and family law) and significantly higher attrition rates amongst female lawyers in many areas of the profession. ${ }^{26}$ Some of the richest discussions on these material realities explore whether patriarchal legal cultures are changed by the increased numbers of women or whether women 'adapt' to essentially male working practices and norms; ${ }^{27}$ whether women perform law differently to men $^{28 ;}$ whether women define success in the legal profession differently to men ${ }^{29}$; and how gender intersects with race, ethnicity and other variables in the legal profession. ${ }^{30}$

${ }^{25}$ Menkel-Meadow Carrie 'The Comparative Sociology of Women Lawyers: The "Feminization" of the Legal Profession' (1986) 24(4) Osgoode Hall Law Journal 897 at 897. Not surprisingly many of these key developments reflected (and informed) evolving feminist legal theories. For an analysis of the competing sway of difference and dominance theories see, for example, MacKinnon Catharine Feminism Unmodified: Discourses on Life and Law Harvard University Press Cambridge 1987 pp 32-45.

${ }^{26}$ See, for example, Larson Magali S The Rise of Professionalism: A Sociological Analysis University of California Press Berkeley 1977; Curran Barbara A The Lawyer Statistical Report: A Statistical Profile of the US Legal Profession in the 1980s American Bar Foundation Chicago 1985; Hagan John 'The Gender Stratification of Income Inequality Among Lawyers' (1990) Social Forces 68(3) 835; Bolton Sharon C and Muzio Daniel 'Can't Live With 'Em; Can't Live Without 'Em: Gendered Segmentation in the Legal Profession (2007) 41(1) Sociology 47; Payne-Pikus Monique, Hagan John and Nelson Robert L 'Experiencing Discrimination: Race and Retention in America's Largest Law Firms' (2010) 44(3) Law and Society 553. For the relevant Australian data see 'Beyond the Statistical Gap: 2009 Court Appearance Strategy for Advancing Appearances by Female Advocates in Australian Courts' Law Council of Australia 2009 pp 10-11 and 15-16; 'National Attrition and Re-engagement Study (NARS) Report' Law Council of Australia 2012 p 9.

${ }^{27}$ Menkel-Meadow Carrie above note 25 at 897. Schultz and Shaw's authoritative overview of women in the legal profession addresses this fundamental question in the context of fifteen civil and common law jurisdictions. Schultz Ulrike and Shaw Gisela (eds) Women in the World's Legal Professions Oxford University Press Oxford 2003.

${ }^{28}$ Butler's Gender Trouble attacks what she considers to be an underlying assumption of feminist theory, namely that there is a gendered identity that requires representation in discourse and politics. It advances from the notion that gender is essentially 'performative' and that the associated 'acts' constitute - rather than express - the illusion of a stable gender identity. Butler Judith Gender Trouble: Feminism and the Subversion of Identity Routledge London 1990.

${ }^{29}$ See for example Menkel-Meadow Carrie 'Portia in a Different Voice: Speculations on a Women's Lawyering Process' (1985) 1 Berkeley Women's Law Journal 39; Menkel-Meadow Carrie 'Exploring a Research Agenda of the Feminization of the Legal Profession: Theories of Gender and Social Change' (1989) 14(2) Law and Social Inquiry 289; Menkel-Meadow Carrie 'Portia Redux: Another Look at Gender, Feminism and Legal Ethics' in Parker Stephen and Sampford Charles (eds) Legal Ethics and Legal Practice: Contemporary Issues Clarendon Press Oxford 1995 p 25.

${ }^{30}$ Tomlinson Jennifer, Muzio Daniel, Sommerlad Hilary, Webley Lisa and Duff Liz 'Structure, Agency and Career Strategies of White Women and Black and Minority Ethnic Individuals in the Legal Profession' (2013) 66(2) Human Relations 245 at 246; Hanlon Gerard 'Institutional Forms and Organizational Structures: Homology, Trust and Reputational Capital in Professional Service Firms' (2004) 11(2) Organization 186; Sommerlad Hilary “The "Social Magic" of Merit: Diversity, Equity, and 
Notwithstanding the 'exceptional' circumstances of the conflicted and transitional societies in which we conducted our research (discussed below), many of these debates were very familiar to the women lawyers we interviewed.

Our views in this paper are also of course influenced by the rich literature on gender and transitional justice. That literature is discussed in detail elsewhere in this issue, but for our purposes a number of themes are particularly relevant. Firstly, we note the tendency in transitional justice to frame the experiences of women in binary terms as either passive victims (e.g. in court proceedings, before truth commissions, applying for reparations) or as agents (e.g. as politicians, NGO activists, negotiators, judges and, lawyers). ${ }^{31}$ Secondly, efforts to ensure that gender based harms form part of the legal architecture of transitional justice and that women are involved in all stages of a peace process have been key features of transitional justice praxis and scholarship since at least the 1990s. ${ }^{32}$ But in spite of this formal and institutional attention to gendered harms and the participatory rights of women, it is clear that the inclusion of women (whether as victims or agents) has offered no guarantee of substantive and material gains. ${ }^{33}$ Moreover there are familiar challenges which relate directly to the work of

Inclusion in the English and Welsh Legal Profession' (2015) 83 Fordham Law Review 2330; Pearce Russell G, Wald Eli and Ballakrishnen Swethaa 'Difference Blindness Vs. Bias Awareness: Why Law Firms With the Best of Intentions Have Failed to Create Diverse Partnerships' (2015) 83 Fordham Law Review 2407.

${ }^{31}$ Waylen above note 18; Ní Aoláin Fionnuala 'Advancing Feminist Positioning in the Field of Transitional Justice' (2012) 6(2) International Journal of Transitional Justice 1 at 5 . For a fascinating account of the struggle to ensure that women were included in the constitutional negotiations to create a Democratic South Africa see Albertyn Catherine 'Women and the Transition to Democracy in South Africa' in Kaganas Felicity and Murray Christina (eds) Gender and the New South African Legal Order Cape Town Juta 1994 pp 54-60.

${ }^{32}$ See for example Mayesha above note 17; Bedont Barbara and Hail-Martinez Katherine 'Ending Impunity for Gender Crimes Under the International Criminal Court' (1999) 6 Journal of World Affairs 65; Campbell Kirsten 'The Gender of Transitional Justice: Law, Sexual Violence and the International Criminal Tribunal for the Former Yugoslavia' (2007) 3 International Journal of Transitional Justice 411. UN Security Council Resolution 1325 (2000) emphasised the need for increased participation of women at all stages of peace processes. In October 2015, the UN Security Council unanimously adopted Resolution 2242 to improve implementation of that agenda. Speaking at the launch of the report Phumzile Mlambo-Ngcuka, Executive Director of the UN Entity for Gender Equality and the Empowerment of Women, stated that 'a growing body of evidence had shown that perhaps the greatest but most under-used tool for building peace was the meaningful inclusion of women'. Full text available at: www.un.org/press/en/2015/sc12076.doc.htm, last accessed 19 January 2016.

${ }^{33}$ For an analysis of the extent to which the gender perspective of UN Security Council Resolution 1325 was reflected in peace agreements signed between January 1990 and January 2010 see Bell Christine and O'Rourke Catherine 'Peace Agreements or Pieces of Paper? The Impact of UNSC Resolution 1325 on Peace Processes and their Agreements' (2010) 59(4) International and Comparative Law Quarterly 941. For a criticism of the resolution as an apt example of 'gender mainstreaming' see Ní Aoláin Fionnuala, Haynes Francesca and Cahn Naomi On the Frontlines: Gender, War, and the Post-Conflict Process Oxford Oxford University Press 2011 pp 11 and 16-18. See also Mertus Julie 'Shouting from the Bottom of a Well: the Impact of International Trials for Wartime Rape on Women's Agency' (2004) 6 International 
women cause-lawyers. For some commentators, the inherent limitations of legalism for women in particular, ${ }^{34}$ may arguably channel precious resources and energies into legal strategies, thus distracting from other potentially more successful tactics, camouflaging root problems and issues, and providing a veneer of legitimacy for fundamentally flawed institutions and procedures. ${ }^{35}$ In addition, in many transitional contexts there are almost always complex intersections between gender and the larger big ' $\mathrm{P}$ ' political struggles. We note in particular that 'opportunities for progress' may in hindsight be viewed as moments of retrenchment, as patriarchal cultures and practices often prove highly resistant to transitional energies once political change is embedded. ${ }^{36}$ Again all of these themes were reflected in the experiences of the women lawyers we interviewed.

Finally, the paper is informed by some of the most relevant academic discussions on the intersection between structure and agency amongst the cause-lawyers we interviewed. That literature is notoriously complex. ${ }^{37}$ At base, the study of the structure agency nexus concerns the extent to which human behaviour or actions (agency) is shaped by forces which are beyond their control. As Marx famously

Feminist Journal of Politics 110 and O'Rourke Catherine Gender Politics in Transitional Justice Routledge London 2013 pp 63-82.

${ }^{34}$ The result for women may be, as suggested by Harris Rimmer, new curtains, cut from the same cloth. Harris Rimmer Susan 'Sexing the Subject of Transitional Justice' Australian Feminist Law Journal (2014) 32(1) p 136 at 123. See further Chinkin Christine, Charlesworth Hilary and Wright Shelley 'Feminist Approaches to International Law: Reflections from Another Century' in Buss Doris and Maji Ambreena (eds) International Law: Modern Feminist Approaches Hart Publishing Oxford and Portland Oregon 2005 p 17-47.

${ }^{35}$ Bell and O'Rourke suggested in a seminal essay in 2007 that transitional justice mechanisms should be assessed strategically, in terms of the likely substantive and material gains for women. Bell Christine and O'Rourke Catherine 'Does Feminism Need a Theory of Transitional Justice? An Introductory Essay' (2007) 1 International Journal of Transitional Justice 23. Similarly Ní Aoláin notes that 'an uncritical and narrowly liberal conception of gender equality directs our gaze away from the cultural, material and geopolitical sites in which transitional justice practices have emerged.' Ní Aoláin above note 31 at 2. See further Yarwood Lisa (ed) Women and Transitional Justice: The Experience of Women as Participants London Routledge (2013).

${ }^{36}$ Ní Aoláin and Hamilton suggest, for example, that 'the moment' of transition can, from a feminist perspective, be one of 'retrenchment'. Such retrenchment, they suggest, is arguably located in the core private/public division that accompanies the rule of law in theory and practice. Ní Aoláin Fionnuala and Hamilton Michael 'Gender and the Rule of Law in Transitional Societies' (March 11, 2009) Minnesota Legal Studies Research Paper No. 09-12 p 102. Citing the specific example of the work of truth commissions, Ní Aoláin and Turner further suggest that the construction of narratives of former conflict often translates into a 'retrenchment of patriarchal family norms and the reassignment of highly circumscribed gender roles for women'. Ní Aoláin Fionnuala and Turner Catherine 'Gender, Truth and Transition' (2007) 16 UCLA Women's Law Journal 229 at 273.

${ }^{37}$ For an overview see Bourdieu Pierre Outline of a Theory of Practice Nice Richard trans Cambridge University Press Cambridge 1997; Giddens Anthony The Constitution of Society: Outline of the Theory of Structuration Polity Press Oxford 1984; Elder-Vas David The Causal Power of Social Structures: Emergence, Structure and Agency Cambridge University Press Cambridge 2010; Archer Margaret Structure, Agency and the Internal Conversation Cambridge University Press Cambridge 2003. 
observed, 'men [sic] make their own history but they do not make it just as they please, they do not make it under circumstances chosen by themselves, but under circumstances directly encountered, given and transmitted from the past. ${ }^{38}$ The structural context, or what Durkheim has termed 'social facts' of the social, political, cultural, legal and of course gendered realties of sites such as Pinochet's Chile, Apartheid South Africa, contemporary Palestine or the other contexts discussed herein inevitably influenced the work of the cause-lawyers we discuss. ${ }^{39}$ However, as we discuss further in the conclusion, the energetic and inventive approach to activism which many of these lawyers brought and bring to their work, provides a useful corrective to an overly deterministic and at worse disempowering reading of the power of structural variables to control human action. Structures are not 'immutable constraints'. ${ }^{40}$ Notwithstanding the durability of some such structural constraints, the agency exercised by women cause-lawyers in even the most difficult of circumstances underlines the fact that in Sarat and Scheingold's terms, they are there to be 'taken on'. ${ }^{41}$

\subsection{Cause Lawyers and 'the Struggle'}

Q. Do you see yourself as a political lawyer?

A: Yes.

Q: Let's define that, tell me what is a political or a cause-lawyer?

A: A political lawyer I would say is a person who does not act for the money but he sees his work as part of the struggle, as the aiding part, as the backbone of the struggle and uses the limited possibilities available through the law to improve the general good. ${ }^{42}$

It is something of a truism that political conflict and struggles against authoritarian regimes may offer somewhat paradoxical opportunities for women's empowerment. ${ }^{43}$ On the one hand the gendered realities of sexual abuse, poverty and what True has called the 'political economy' of violence against women, which is so often

\footnotetext{
${ }^{38}$ Marx Karl 'The Eighteenth Brumaire of Louis Bonaparte' in Feuer Lewis (ed) Marx and Engels: Basic Writings on Politics and Philosophy Doubleday New York 1959 p 320.

${ }^{39}$ Durkeim Emile The Rules of Sociological Method Free Press republished Free Press New York 2014, especially chapters one and two.

${ }^{40}$ Ewick Patricia and Silbey Susan The Common Place of Law: Stories from Everyday Life University of Chicago Press Chicago 1998 p 41.

${ }^{41}$ Sarat Austin and Scheingold Stuart 'The Dynamics of Cause Lawyering' in Sarat Austin and Scheingold Stuart (eds) The Worlds Cause Lawyers Make: Structure and Agency in Legal Practice Stanford University Press California 2005 p 7.

${ }^{42}$ Personal interview with human rights lawyer, Ramallah, Palestine, 20 May 2014. As in other contexts, female interviewees sometimes employed the male pronoun to refer to women and men.

${ }^{43}$ Meintjies Sheila, Pillay Anu and Turshen Meredeth 'There is No Aftermath for Women' in Meintjies, Pillay and Turshen Meredeth (eds) above note 16 at 7.
} 
synonymous with conflict, has been well documented. ${ }^{44}$ On the other hand, the involvement of men in conflict, whether in the context of involvement in armed organisations, imprisonment, or even being killed or injured, may offer the chance for women to become what Meintjies et al have referred to as 'agents of change.' ${ }^{45}$ Such agency is not restricted to the familial sphere and may be reflected in community, political or professional life. ${ }^{46}$ Recalling her experience of the first intifada, one Palestinian lawyer in the West Bank told us:

The mum became a huge kind of 'responsibility-taker' in a way that wasn't [the case] in the past. In addition women were entering the political sphere and not just the political sphere, but the activist sphere ... many of the men actually were imprisoned and what does that mean for the woman that has to stay home and become the breadwinner and take care of the family and do all the traditional [male] roles?... I think all of that kind of spurred more of an understanding of what their rights could be or should be. ${ }^{47}$

In the legal profession, the sheer volume of arrests, trials and human rights violations associated with periods of protracted violence and conflict not surprisingly creates opportunities for lawyers - both male and female - who are willing to take on such 'political' cases. As noted above, across the six jurisdictions we interviewed a total of 40 women human rights activists and lawyers. In some instances, these women have become what Hansford has described as 'legendary' lawyers. ${ }^{48}$ Certainly figures such as Leah Tsemel, Gaby Lasky, Carmen Hertz, Radhia Nassaoui, Yasmin Sooka, Priscilla Jana and others interviewed for this project have all received national or international accolades as well as criticism and harassment for their work as 'cause' lawyers. For some of these women, their work on gender related issues intersected with causelawyering on other broader political struggles.

I was involved in women's organisations from the very beginning and thought that was the direction I was going ... when I came back after having that time outside of Israel and

\footnotetext{
${ }^{44}$ Giles Wenona and Hyndman Jennifer (eds) Sites of Violence: Gender and Conflict Zones University of California Press Berkeley 2004; Buvinic Mayra, Das Gupta Monica, Casabonne Ursula and Verwimp Philip 'Violent Conflict and Gender Inequality: An Overview' (2013) 28(1) World Bank Research Observer 110; True Jacqui The Political Economy of Violence Against Women Oxford University Press Oxford 2012. ${ }^{45}$ Meintjies, Pillay and Turshen (eds) above note 16 at 16 . Of course some women also become directly involved in armed struggle themselves. See, for example, Ibanez Ana Cristina 'El Salavador: War and Untold Stories, Women Guerrillas' in Mosner Caroline O N and Clark Fiona C (eds) Victims, Perpetrators or Actors: Gender, Armed Conflict and Political Violence Zed Book London 2001 p 117; Yarwood above note 35.

${ }^{46}$ Bell and O'Rourke above note 33 at 41. See further Ní Aoláin Fionnuala, Hayes Francesca and Cahn Naomi On the Frontlines: Gender, War and the Post-Conflict Process Oxford University Press Oxford 2011 p 6; O'Rourke above note 33 pp 4-5.

${ }^{47}$ Personal Interview with international human rights lawyer, Ramallah, Palestine, 22 May 2014.

${ }^{48}$ Hansford Justin 'The Legal Ethics of Nelson Mandela' forthcoming New York Law Review, available at: www.ssrn.com abstract no 2556320.
} 
getting some new perspective, I realised that what I think is really the most urgent and most important thing to deal with is Palestinian rights. ${ }^{49}$

I was involved first as an activist in student politics, protesting against the regime ... when I became a lawyer I was involved in defending students and human rights activists ... I was also a member of a feminist association and we worked on what we saw as political issues as well, including delicate and sensitive cases such as rape or sexual harassment or any kind of assault that is directed against a girl or a woman. I worked on a case about an old lady seventy years old, [name] who was harassed on all levels economically, sexually, socially all levels and it took two years campaign of two years in order to get her justice. Many other cases such as representing a 12 year child who was the victim of rape or sexual harassment where the judge and prosecutor wish to dismiss the case because of her age... such cases are 'feminist' on the surface but of course behind such cases there are many political waves. ${ }^{50}$

Other women cause-lawyers viewed themselves primarily as political activists engaged in the broader political struggle and their work was seen as an expression of their commitment to the political struggle as a whole. In effect for some such lawyers, there appears little difference between law and politics, as they set about 'fabricating political action with legal tools and legal action that responds to political necessity' ${ }^{51}$ Indeed for some, the status of lawyer was one that allowed an expression of their activism, a space to work on what Sarat and Scheingold term 'a transformative agenda' that is often not available in other walks of life in repressive regimes. ${ }^{52}$

I myself was an activist, a political activist before becoming a lawyer you know. I was always of course a supporter of the ANC ... in my student days I became a very active person in the Black Consciousness movement ... And then I qualified as a lawyer ... I was also an activist; then I had become a very active member, underground member of the ANC and part of an ANC cell. But that's beside the point. The point is that to become a human rights lawyer in any conflict situation I think you cannot separate your moral duties and your political duties from your legal duties. I think it's all one. ${ }^{53}$

I've been a lawyer since 1985 so as with many students I was a university activist and then when I started being a lawyer I started defending political detainees, political

\footnotetext{
${ }^{49}$ Personal interview with international human rights lawyer, Tel Aviv, Israel, 14 May 2014.

${ }^{50}$ Personal interview with cause lawyer, Tunis, Tunisia, 16 June 2014.

${ }^{51}$ See Sarat and Scheingold above note 41 at 9; Boukalas Christos 'Politics as Legal Action \Lawyers as Political Actors: Towards a Reconceptualisation of Cause Lawyering (2013) 22(3) Social and Legal Studies 395; Michalowski Raymond 'All or Nothing: an Inquiry into the (Im)Possibility of Cause Lawyering Under Cuban Socialism' in Sarat Austin and Scheingold Stuart A Cause Lawyering: Political Commitments and Professional Responsibilities Oxford University Press Oxford 1998.

52 Sarat and Scheingold above note 21 at 20.

${ }^{53}$ Personal interview with international human rights lawyer, Cape Town, South Africa, 12 August 2014.
} 
prisoners arrested for freedom of expression issues and so on ... I like the profession. Being a lawyer has been the only perhaps the only area of national life that Ben Ali could not co-opt. ${ }^{54}$

I went into exile after the coup because my husband was killed so I left the country with my son and I was away for three years. And when I came back I went immediately and started to work at the Vicaría de la Solidaridad - as a full time lawyer there at the Vicaría. And that was at the beginning of '77. I went there because of my political convictions. I went there to defend the people who were being persecuted and to denounce the crimes that were happening. It was the first real space of resistance that opened in Chile. And that was the role that we played. We were a generation that they tried to eliminate, that they tried to persecute, we were that 60's generation. That's the reason I became a human rights lawyer. ${ }^{55}$

Needless to say that for many such lawyers there were (and in some cases still are) significant personal consequences for engagement in such work. In extremis, in Cambodia the systematic murder of lawyers, judges and professors was part of the genocidal strategy of the Khmer Rouge to eradicate the educated, the bourgeoisie and all others deemed a threat to the regime. ${ }^{56}$ In Chile, while some lawyers who were deemed to be affiliated to leftist or communist organisations were murdered, disappeared or expelled, lawyers did enjoy some degree of protection because of their profession, international or local affiliations. Even so, the violence and intimidation was often directed at others associated with cause lawyers. ${ }^{57}$

The protection of the Church gave us some kind of immunity, some level for various reasons ... the Cardinal had a permanent interlocutor with the military he could talk to

\footnotetext{
54 Personal interview with cause lawyer and prisoner rights' activist, Tunis, Tunisia, 20 June 2014. Zine al-Abidine Ben Ali was the authoritarian President of Tunisia for 23 years. In January 2011 he was forced to resign and flee to Saudi Arabia; he was subsequently sentenced in absentia for embezzlement and corruption.

${ }^{55}$ Personal interview with international human rights lawyer, Santiago, Chile, 28 April 2014. The Vicariate of Solidarity was an agency of the Chilean Catholic Church under the Archdiocese of Santiago which became one of Chile's most high profile NGOs litigating on behalf of political prisoners and others abducted and tortured by the Pinochet regime. Its effectiveness and ability to operate was widely attributed to the protection of the Church.

${ }^{56}$ It is estimated that the Khmer Rouge regime murdered all but 6-12 of the country's 400-600 lawyers. See Donovan Dolores A 'Cambodia: Building a Legal System from Scratch' (1993) 27(2) The International Lawyer 445. One of our Cambodian interviewees stated: 'In Cambodia they killed not just lawyers, they killed everybody - they killed a whole generation. Today you'll hardly find people of my generation aged between 50 and $60 \ldots$ those that are the foundation of a country, those that are educated - teachers, lawyers, doctors, psychiatrists, engineers, they all were gone ... lawyers, particularly lawyers, you know, I think only a few survived'. Personal interview with NGO lawyer, Phnom Penh, Cambodia, 10 March 2014.

${ }^{57}$ See Snyder Edward C 'Dirty Legal War: Human Rights and the Rule of Law in Chile 1973-1995' (1994) 2 Tulsa Journal of Comparative and International Law 253.
} 
them. Almost all of our activities were public they weren't clandestine. We were the main interlocutor with the UN we would go to Geneva but there were exceptions ... In my case they killed the little woman who worked in my house who helped me with cleaning my house so she's one of the people officially recognised as victim of human rights violations. They killed her to intimidate me. ${ }^{58}$

In other contexts, pressure came in the form of threats, harassment (often sexualised) and intimidation by the police, military or even opposing lawyers. An Israeli lawyer highlighted the particular danger of sexual violence - whether actual or implied when she was identified as a human rights activist.

One of them was an incident I had where I was verbally attacked for the work I did and for being a woman. In Tel Aviv while sitting in a bar. This was a bar we used to come after work with the office so he recognised [named cause-lawyer, head of the firm] of course and then me by association. The next week while I was there not surrounded by colleagues and male colleagues and kind of unprotected he just started saying horrible things. And what was worse for me about that experience was that I didn't respond the way that I wanted to, I was just so shocked. He said 'if I see you in a dark alley you should be raped.' And the management in the place did nothing. I ended up leaving. It took me a while to realise how much it influenced me because I found myself sitting at home and saying oh, I should have said this, I should have did that and this is very typical for kind of victims of sexual harassment... So I think this incident kind of left a stamp on me. Later on when the threats and the derogatory speech were more general, you know, directed at all people doing human rights, being a fifth wheel and traitors etc., stuff that even politicians here say, I think it kind of always brought me back to that incident. ${ }^{59}$

Another human rights activist in Israel recounted similar instances of being threatened with both physical and sexual violence in custody, including being shackled in a cell with other female detainees and tortured with a taser gun. ${ }^{60}$ In the case of Tunisia, such direct intimidation was also over-layered with gendered efforts to diminish the reputation of the women lawyers.

It was difficult for us because they would beat us sometimes, but they would beat us less than they do the men. I was actually kicked by one of the policemen wearing those big heavy boots and my leg was swollen for a while. But they would more often say we were women with a bad reputation ... they would always accuse us of being informants, of cooperating with foreigners, as 'sell-outs' as it were, as well as being women of bad reputation. ${ }^{61}$

\footnotetext{
${ }^{58}$ Personal interview with international human rights lawyer, Santiago, Chile, 28 April 2014.

${ }^{59}$ From a personal point of view she also noted that dealing with the military courts and witnessing the suffering that was inflicted on young people especially, day after day, eventually took a toll. Personal interview with legal academic and human rights activist, 14 May 2014.

${ }^{60}$ Personal interview with human rights activist, Ramallah, Palestine, 22 May 2014.

${ }^{61}$ Personal interview with cause lawyer, Tunis, Tunisia, 20 June 2014.
} 
Interviewees also talked to us about the personal, familial and relationship toll of involvement in cause-lawyering in such contexts. In some instances, this appeared a more extreme version of the 'total commitment' and long working hours complaints associated with commercial legal firms. ${ }^{62} \mathrm{~A}$ well-known Israeli cause lawyer noted:

'There used to be a time when I read the newspaper in the morning and I knew that in the evening I would represent the person who planted the bomb ... It was difficult for my family - very much, oh very much. To be hated, you know, and it was sheer hatred but I didn't care so much, for me it was okay'.63

Speaking to the South African context, a former ANC activist noted that being a 'struggle lawyer' like other forms of intense political activism during the conflict and transition was not compatible with 'normal' family life:

I think being a struggle lawyer is - it's not nine to five, firstly. It can be at any time and normally all the arrests were only ever happening from night onwards - so you couldn't have a nine to five. So there's the time that you have to put in, but there's also the kind of danger you were in. ${ }^{64}$

As in other contexts, the familial consequences of such work and activism were often most acutely felt once the 'adrenalin' of conflict began to subside - in the case of South Africa after the 1994 elections which saw the ANC came to power and Nelson Mandela was elected President. She continued:

I don't think there was a single, well maybe a handful of activists that still have their original partners that they had when they started out. For the rest, no, divorce rate is very high ... I think the amount you had to put in, you know, and it wasn't just time. You had to put yourself in and the implications of that on family and that were quite high ... there was also the gender issue. So the female activists, you know, we're also not sitting in our slippers anymore, you know, we can do things for ourselves. And we have opinions and for those who became activists it meant they fought a bitter battle at home as well for their voices to be heard ... and after the elections where things started settling down and now we all have to find ways of getting into a normal life. What is a normal life? You know, you've lived on this adrenaline for so long. ${ }^{65}$

\footnotetext{
${ }^{62}$ For those who accept the 'double-burden' as a given, the reform of working practices - in particular the demands for long and unsociable working hours and the corresponding celebration of the 'ideal employee' as one who works full-time, over-time and with no career interruptions - is an absolute priority. See Cha Youngjoo 'Overwork and the Persistence of Gender Segregation in Occupations' (2013) 27(2) Gender and Society 158; Williams Joan C Unbending Gender: Why Family and Work Conflict and What to do About it Oxford University Press New York 2000; Korzec Rebecca 'Working on the "MommyTrack": Motherhood and Women Lawyers' (1997) 8 Hastings Women's Law Journal 117.

${ }^{63}$ Personal interview with human rights lawyer, Ramallah, Palestine, 20 May 2014.

${ }^{64}$ Personal interview with former ANC and human rights activist, Johannesburg, South Africa, 15

August 2014.

${ }^{65}$ Personal interview with former ANC and human rights activist, Johannesburg, South Africa, 15 August 2014.
} 
In sum, many of the issues raised by the women cause-lawyers we interviewed resonated with the experiences of male cause-lawyers elsewhere. The explicit politicisation of lawyering and the conception of legal settings as a site of struggle are very familiar themes in the cause lawyering and sociology of lawyers literature. In the context of women lawyers, their experience of struggle also intersects in complex ways with gender - both in terms of the areas in which they work (e.g. whether they are focused explicitly on gender equality or other aspects of political and social struggle) and in the ways in which they are treated by state officials, legal adversaries and others. Moreover, both during periods of conflict and transition (which we discuss in more detail below) the price paid for doing such work on personal, professional and familial level can be high indeed.

\subsection{Cause Lawyers and the Transition}

As discussed above, there is now a significant literature on gender, activism and transitional justice. One of the successes for feminists over the last two to three decades has been the increased recognition of gender-based harms and violations as a key focus of transitional justice. ${ }^{66}$ There is a sense, as O'Rourke has noted, that 'the doctrine and institutions of international law have never been more supportive of delivering positive human rights outcomes for women from domestic processes of transitional justice. ${ }^{67}$ Specifically numbered among the 'gains' in this area are the inclusion of crimes of sexual violence as a 'grave breach' of the Geneva conventions ${ }^{68}$; the establishment of rape as a crime against humanity in the Rome statute ${ }^{69}$ and what Franke refers to as 'paradigm-shifting' indictments and convictions at the International Criminal Tribunal for Rwanda (ICTR) and the International Criminal Tribunal for the Former Yugoslavia (ICTY) - variously recognising sexual violence as an element of genocide, torture and inhumane treatment. ${ }^{70}$

\footnotetext{
${ }^{66}$ See for example Campbell above note 32 at 411.

${ }^{67} \mathrm{O}^{\prime}$ Rourke above note 33 at 7.

${ }_{68}$ Copelon Rhonda 'Surfacing Gender: Re-Engraving Crimes Against Women in Humanitarian Law' (1994) 5 Hastings Women's Law Journal 243; Copelon Rhonda 'Gender Crimes as War Crimes: Integrating Crimes Against Women into International Criminal Law' (2000) 46 McGill Law Journal 217.

${ }^{69}$ Oosterveld Valerie "The Definition of "Gender" in the Rome Statute of the International Criminal Court: A Step Forward or Back for International Criminal Justice?' (2005) 18 Harvard Human Rights Journal 55.

${ }^{70}$ Franke Katherine M 'Gendered Subjects of Transitional Justice' (2006) 15(3) Columbia Journal of Gender and Law 813 at 816-817. The Inter-American Commission of Human Rights also accepted in Gladys Carol Espinoza Gonzáles $v$ the Republic of Peru Case 11.157, Inter-American Commission of Human Rights Report No 67/11, 31 March 2011 that rape constituted torture. See further Green Jennifer, Copelon Rhonda, Cotter Patrick and Stephens Beth 'Affecting the Rules for the Prosecution of Rape and Other Gender-Based Violence Before the International Criminal Tribunal for the Former Yugoslavia: A Feminist Proposal and Critique' (1994) 5 Hastings Women's Law Journal 171; Askin Kelly D ‘A Decade of the Development of Gender Crimes in International Courts and Tribunals: 1993 to 2003' (2004) 11(3)
} 
For the non-retributive variants of transitional justice, such as truth recovery or reparations, there has also been incremental but important progress. The early Latin American truth commissions were rightly berated for failing to recognise gender as a key dimension of truth seeking. ${ }^{71}$ This was at least partially corrected in the Guatemalan, South African and Peruvian commissions in which sexual violence was addressed under the banner of torture and ill-treatment. ${ }^{72}$ Concerns have nonetheless persisted about the issue of under-reportage of instances of sexual violence ${ }^{73}$ and the aforementioned dangers of confining the frame of reference for gender-based harms to a narrow conception of sexual violence. ${ }^{74}$ Ross meanwhile has produced a probing analysis of women's relationship to testimony and in particular the types of violence and suffering about which they choose (or feel pressured) to remain silent. ${ }^{75}$ From a practical point of view others have suggested that well-designed truth commissions that yield valuable information about the patterns and themes of gender-based harms are of limited value if they do not help to yield substantive and material gains for women designed to repair as much as possible the damage done by such harms. ${ }^{76}$ With regard to reparations, there has been significant work done to try to broaden the gaze of reparations (e.g. to recognise forced 'marital unions', domestic labour or property loss) $)^{77}$ and indeed to advocate for a transformative version of gender reparations which can 'subvert existing patriarchal structures' rather than simply restore a flawed status quo ante. ${ }^{78}$

Human Rights Brief 1; and Bactrach Michael 'The Protection and Rights of Victims under International Criminal Law' (2000) 34(1) The International Lawyer 7.

${ }^{71}$ Nesiah Vasuki et al 'Truth Commissions and Gender: Principles, Policies, and Procedures' (July 2006) International Center for Transitional Justice $\mathrm{p} 7$.

72 See Bell and O'Rourke above note 35 at 28.

${ }^{73}$ For example, just over 300 instances of sexual violence were reported to the UN-sponsored El

Salvador Commission (1993). This is widely held to be a mere fraction of the real figure with underreportage variously attributed to the social stigma attached to sexual violence, fears of ostracisation or retaliation, and the failure of the commission to proactively solicit information on the theme. See Hoover Amelia 'Conflict and Gender: Data Overview' Benetech Human Rights Data Analysis Group Yale University (November 2009) 2. Full text available at $<\underline{w w w . p r e v e n t g b v a f r i c a . o r g / w p-}$ content/uploads/2013/10/Conflict and Gender Data Overview.pdf $>$ (last accessed 18 April 2016).

${ }^{74} \mathrm{Ní}$ Aoláin further cautions that the processes that 'construct' truth, in particular the privileging of certain kinds of memory (associated with 'public' allocations of power and territory), may have 'a consistent patriarchal under-current'. Ní Aoláin and Turner above note 36 at 273.

${ }^{75}$ Ross Fiona C Bearing Witness: Women and the Truth and Reconciliation Process in South Africa Pluto Press London 2003. See further Millar Hayli ‘Facilitating Women's Voices in Truth Recovery: An Assessment of Women's Participation and the Integration of a Gender Perspective in Truth Commissions' in Durham Helen and Gurd Tracey (eds) Listening to the Silences: Women and War Martinus Nijhoff Boston Leiden 2005 p 171-222.

${ }^{76}$ See Bell and O'Rourke above note 35.

${ }^{77}$ Rubio Marin Ruth 'The Gender of Reparations: Setting the Agenda' in Rubio Marin Ruth (ed) What Happened to the Women: Gender and Reparations for Human Rights Violations Social Science Research Council New York 2006 p 31.

${ }^{78}$ Urban Walker Margaret ‘Transformative Reparations? A Critical Look at a Current Trend in Thinking about Gender-Just Reparations' (2015) International Journal of Transitional Justice 1. Walker uses the 
Unsurprisingly, in our interviews and discussions with female cause-lawyers across the relevant jurisdictions we found the same variety of experiences with regard to the areas in which people worked during the transition as during the conflict or 'struggle' phase. For example, some lawyers were engaged in struggles to ensure that gender related issues were included in the transitional justice mechanisms operating in their particular jurisdiction while others applied themselves to specific aspects of dealing with the past work such as prosecution of past human rights abuses or filing civil actions on behalf of victims - or a combination of the two. We were also interested in exploring the ways in which their cause-lawyering was done, the networks in which they worked and their relations with civil society. At a conceptual level, we also sought to examine the ways in which activism and gender related struggles were imagined as part of the broader process of constructing and reproducing both the transition itself and the previous years of struggle.

In the same way as conflict and struggle provided some opportunities for female cause-lawyers, a strong theme permeating our interviews was the notion of transition as a 'window of opportunity' ${ }^{79}$ For example one lawyer and a founding member of the Women's National Coalition in South Africa, told us:

People always said to us, you know, the first five or ten years is a great window of opportunity in every way - all the other African countries told us because they'd been down our road before - and although we thought that South Africa was the exception, it absolutely wasn't. So they were just saying 'use that space because it all really closes down' and of course it does close down. Institutions slowed down, bureaucracies become embedded - that kind of idea that 'we're going to change the state and it's going to be open and participative and efficient' disappears very quickly. ${ }^{80}$

As O'Rourke, Keck and Sikkind and others have argued, ${ }^{81}$ the potential for feminist lawyers and civil society organisations to seize such opportunities often requires a combination of using international human rights standards, transnational mobilisation with international partners, as well as strategic litigation and mobilisation in the domestic context. In addition, in some transitional jurisdictions (including Northern Ireland where we live and work), heightened awareness of past rights abuses has seen increased legal, political and civil society attention focused on creating a more human rights aware culture as a buttress against such atrocities

useful illustration of the Moroccan Reconciliation Commission which apportioned benefits among family members of deceased victims in ways that departed from Morocco's gender-biased inheritance law, resisting the established gender hierarchy.

${ }^{79}$ Gready Paul The Era of Transitional Justice Routledge London 2011; Root Rebecca 'Through the Window of Opportunity: the Transitional Justice Network in Peru' (2009) 31(2) Human Rights Quarterly 473.

${ }^{80}$ Personal interview with legal academic and human rights activist, Johannesburg, South Africa, 13

August 2014.

${ }^{81}$ Keck, Margaret and Kathryn Sikkink Activists Beyond Borders: Advocacy Networks In International Politics Cornell University Press New York 1998; O’Rourke above note 33. 
happening again. ${ }^{82}$ Even in contexts where such favourable conditions existed, causelawyers working on gender-related issues were sometimes struggling to make progress in practice. As one self-identified cause-lawyer prosecutor in Chile told us;

Even though in 2005 we passed a major domestic violence legislation even now the criminal courts don't want to hear these cases. They don't often convict maybe because there's this understanding, a basic understanding that women's issues are not human rights issues, they are family issues. In the cases of sexual violence and torture in the dictatorship; it has also been extremely difficult. I have spent over a year arguing for the cases to be heard by members of the Appelate court, just like all the other cases of the former dictatorship... We are trying to get them to understand that the violence suffered by women was a violence that was different from that of men but that it was also a kind of torture. ${ }^{83}$

In the case of Chile, this disconnect between the crimes of the past and receptiveness to gender based arguments in the transition speaks to the durability of a conservative and patriarchal political and legal culture. ${ }^{84}$ In a similar vein in Cambodia, despite the fact that rape, sexual exploitation, sexual slavery and 'forced marriages' were all features of the Khmer Rouge regime, the Extra-ordinary Chamber in the Courts of Cambodia has only managed (after persistent lobbying by activists) to add 'forced marriages' to the charge sheet in one case - Case 002. ${ }^{85}$ A number of the cause lawyers we spoke to argued that such past abuses underpinned the culture of impunity regarding sexual violence in contemporary Cambodia. As one international lawyer told us:

A UN report came out in June 2013 on violence against women and it shows that incidents of rape in Cambodia is even higher than other countries in the region. So it's really a big issue and domestic violence is occurring a lot... Men can buy women whenever they want, they can marry them whenever they want and they can beat them

\footnotetext{
82 Roht-Arriaza Naomi and Mariezcurrena Javier (eds) Transitional Justice in the Twenty-First Century: Beyond Truth Versus Justice Cambridge University Press Cambridge 2006; Harvey, Colin 'Bringing Humanity Home: A Transformative Human Rights Culture in Northern Ireland' in McAlinden Anne Marie and Dwyer Clare (eds) Criminal Justice in Transition Hart Oxford 2015 p 47-67.

83 Personal interview with Chilean human rights lawyer, Santiago, Chile, 28 April 2014.

${ }^{84}$ Macias Teresa "“Tortured Women and Hungry Widows": Patriarchal Neoliberalism and the Logic of Compensational Justice in Chile' (2013) 28(2) Affilia 126.

${ }^{85}$ Killean Rachel 'An Incomplete Narrative: Prosecuting Sexual Violence Crimes at the Extraordinary Chambers in the Courts of Cambodia' (2015) 13 Journal of International Criminal Justice 331. See also Elander Maria (in this issue). In April 2014, the ECCC Co-Prosecutor made two announcements that the Prosecution were 'requesting the investigation of sexual or gender-based violence' as an element of the broader charges in two further cases (003 and 004). The Cambodian government is opposed to these cases going ahead, arguing that the prosecutions in cases 001 and 002 should suffice, and that further prosecutions will 'lead the country into instability'. See further Brinkley Joel 'Justice Squandered: Cambodia's Khmer Rouge Tribunal' (2013) World Affairs Journal. Available at: www.worldaffairsjournal.org/article/justice-squandered-cambodia\%E2\%80\%99s-khmer-rougetribunal. Accessed 10 May 2016.
} 
whenever they want and rape them so there are very little consequences because they are above the women ... the legal system doesn't work so when a woman is raped and she goes to the police and the police will try to settle the dispute by negotiating a price with the perpetrator. The police will get maybe $25 \%$ and then the rest goes to the family and everybody shuts up and it's justice. And for me, it's fine that they do this but they cannot drop the criminal prosecution, it's fine that he pays compensation and they agree on it but he has to be prosecuted as well. ${ }^{86}$

In other contexts, where there has been a much more dramatic political and legal transformation, the obstacles and cultural silences on gender-related issues facing cause-lawyers can be all the more insidious. For example, in his first State of Nation address to Parliament, former President Nelson Mandela said 'freedom cannot be achieved unless women have been emancipated from all forms of oppression.' ${ }^{87}$ Evidence of the importance of gender equality and women's rights are replete in the new South African Bill of Rights which is rightly acknowledged as one of the most progressive in the world. ${ }^{8}$ Indeed for some commentators, gender became a 'moral touchstone' by which to judge the transition in South Africa. ${ }^{89}$ Notwithstanding the undoubtedly important political and legal advances that have been made, rape and sexual violence against women remains an endemic problem. ${ }^{90}$ Even within the cause-lawyer community, gendered silences remain - not least because of the veneration of causelawyers themselves who for many are a symbol of all that was good about the South African struggle. For example, one cause-lawyer related the story of a fellow activist who had been abused by her husband (himself a cause-lawyer):

she's probably one of the famous women and she came to me and she revealed the subject of domestic abuse. And I said to her, okay, we're going to help you and we're going to take your case out. And inside the movement there was such a powerful silence that she should not break, but even though we were willing to help her take the risk, she just didn't have the guts to do it because no one wanted her to speak about it. And I mean I keep saying to the women that, you see, we will never deal with domestic violence in our

\footnotetext{
${ }^{86}$ Personal Interview with international human rights lawyer, Phnom Penh, Cambodia, 10 March 2014. The report cited is Fulu Emma et al ‘Why Do Some Men Use Violence Against Women And How Can We Prevent It? Quantitative Findings from the United Nations Multi-Country Study of Men and Violence in Asia and the Pacific' (2013) UNDP, UNFPA, UN Women and UNV Asia-Pacific Regional Joint Programme for Gender-Based Violence Prevention.

${ }^{87}$ Cited in Cowan Ruth B 'Women's Representation on the Courts in the Republic of South Africa' (2006)

6 (2) University of Maryland Law Journal of Race, Religion, Gender \& Class 292.

${ }^{88}$ As above at 291.

${ }^{89}$ Albertyn Catherine 'Defending and Securing Rights Through Law: Feminism, Law and the Courts in South Africa' (2005) 32(2) Politikon: South African Journal of Political Studies 217.

${ }^{90}$ Jewkes Rachel and Naeema Abrahams 'The Epidemiology of Rape and Sexual Coercion in South Africa: An Overview' (2002) 55(7) Social Science \& Medicine 1231.
} 
country unless that story of abuse is told in our country, and that's the story of the struggle that's not told. ${ }^{91}$

For this interviewee, such cover-up within the ranks of 'struggle lawyers' reflected more broadly on the legal profession:

It's not a profession that took care of people and, you know ... nobody wanted to touch another lawyer and I found that like the legal hypocrisy really incredible ... I kind of thought this is a terrible profession, there is no sense of solidarity, caring or solidarity. ${ }^{92}$

As noted above, a key element to the advancement of gender based issues for causelawyers in all of the jurisdictions studied has been the development of relationships with civil society organisations, NGOs and other activists both locally and internationally. For many such organisations networks of 'organized women' are the driving force for gender-related struggles in transitional societies. ${ }^{93}$ Such relations between lawyers and civil society organisations have been a rich source of analysis for a number of years in the cause-lawyering literature more generally. For some, there are risks that if lawyers assume too much prominence in such social movements, strategies may become overly legalistic and thus divert scarce resources from other potentially more transformative methods of political and social struggle. ${ }^{94}$ Other accounts suggest that a range of variables including the local legal and political context in which lawyers and social movements are operating, the capacity of the movement, the professional and personal imperatives of the lawyers themselves (as above, some of whom may have been 'activists first') and other factors may contribute to a more fluid and dynamic relationship wherein the capacity for lawyers and legal strategy to dominate is reduced..$^{95}$ The latter variant of the relationship was, broadly speaking, the most common in our research on women cause lawyers. As one prominent lawyer in South Africa responded in relation to the question of whether lawyers tended to dominate in the social movements in which she was involved:

Not in the women's movement, no, because you were held to account. I mean in fact they changed me in many ways ... because I did go in as a bit of a lawyer; you do learn to be the person who says how it is, right, 'cause that's what we do as lawyers; we pronounce on certainty, even though we know it's uncertainty. You know, and they were having

\footnotetext{
${ }^{91}$ Interview with international human rights lawyer, Johannesburg, South Africa, 16 August 2014.

${ }_{92}$ As above.

${ }_{93}$ Waylen above note 18.

${ }^{94}$ Scheingold Stuart A The Politics of Rights: Lawyers, Public Policy and Political Change University of Michigan Press Ann Arbor $2^{\text {nd }}$ ed 2004; Jones Lynn C 'The Haves Come Out Ahead: How Cause Lawyers Frame the Legal System for Movements' in Sarat Austin and Scheingold Stuart A (eds) Cause Lawyers and Social Movements Stanford University Press Stanford 2006 p 182-196.

${ }^{95}$ McCann Michael (ed) Law and Social Movements Ashgate Aldershot 2006; Boutcher Steven 'Mobilizing in the Shadow of the Law: Lesbian and Gay Rights in the Aftermath of Bowers v. Hardwick' (2011) 31 Research in Social Movements, Conflict and Change 175.
} 
none of that. So it was a wonderful experience for me because I was really challenged and questioned... I had a valid voice but then so did other people ... I mean I remember just learning, having to learn very quickly, that, you know, that was my place and that I had validity and I had things to say but, you know, I was not the oracle. ${ }^{96}$

We have noted that 'the moment' of transition can, from a feminist perspective, be viewed as one of 'retrenchment'. ${ }^{97}$ Ní Aoláin develops this argument by suggesting that, whilst transition can create new 'opportunities, ideas and sites of intervention' that newness can equally hide 'deep pitfalls of structural and entrenched gender discrimination'. ${ }^{98}$ Certainly in some contexts, the political negotiations and compromises required to build broad fronts in civil society during a transition appeared to require 'sacrificing' gendered issues in order to sustain importance alliances. In South Africa for example, leaders in the women's movement told us that they 'really had to fight the men' to prevent the customary law provisions in the constitution being used to undermine the rights of rural women because of the ANC's desire to placate tribal leaders. ${ }^{99}$ Similarly, in Chile as one veteran lawyer and civil society leader told us:

Violence against women was a product of the international agenda - in Latin America and more particularly here in Chile. On the other hand, our demands, the women's movement demands, have been hijacked by the Catholic Church. The Catholic Church was hugely important during the dictatorship and one of the issues on the table at the beginning of the transition period was that of women's rights. But this was an issue that was negotiated with the Catholic Church, and I can say this because I was one of the participants of that process. I was one of the few who insisted that the issue of abortion, for example, had to be tackled straight on, but the political leaders of the opposition would tell us: "Those issues cannot be touched". It was only two years ago that we had divorce in Chile! 100

Finally, as is evidenced across the jurisdictions we have been researching, there is a complex relationship between material and symbolic advances for women and the ways in which these societies imagine their own transition and in some instances the cause-lawyers who have been seeking to advance such struggles. Inevitably, such

\footnotetext{
${ }_{96}$ Personal interview with legal academic and human rights activist, Johannesburg, South Africa, 13 August 2014.

${ }^{97}$ See Ní Aoláin and Turner above note 36 at 273. In the case of South Africa, Albertyn similarly cautions that constitutionalism and rights can introduce a dangerous sense of apathy: 'One of the tasks for women in South Africa is to ensure that the interim Constitution, with its rights framework, is not used in a way which restricts rather than furthers the goal of gender equality ... all of this needs to take place within a vision of social reconstruction that addresses the material bases of women's inequality'. Albertyn Catherine above note 31 at pp 62-63.

${ }^{98}$ Ní Aoláin above note 31 at 3.

${ }^{99}$ Personal interview with legal academic and human rights activist, Johannesburg, 13 August 2014.

100 Personal interview with Chilean human rights lawyer, Santiago, Chile, 30 April 2014.
} 
processes are shaped by the previous era of conflict or authoritarianism. The temporal nature of 'transitional' justice arguably creat

es false dichotomies between the exotic and terrible violence of the past and the assumed improvements of any new dispensation. ${ }^{101}$ For example, as one interviewee told us in Tunis, 'amongst the biggest lies of the former regime is that Tunisia was the land of women's freedom and equal rights. ${ }^{102}$ Similarly, in Israel, a state which is still very much in conflict and which is certainly demonstrating increased authoritarian tendencies, several cause-lawyers and activists critiqued the efforts of the Israeli government to 'pinkwash' the occupation and associated abuses of Palestinians by constantly referring international audiences to the country's comparatively 'progressive legislation and policies on gender and LGBT rights.' ${ }^{103}$

These contests regarding the ways in which both past and present are constructed and reproduced are also part of the struggle of cause-lawyers. It is all too easy for neat narratives to dominate and for what Mazzei describes as 'the voices in the cracks' to be silenced. ${ }^{104}$ In South Africa for example, the veneration of struggle lawyers can produce narratives where both women and black lawyers are 'written out' of the ways in which the struggle and transition are remembered. Cause lawyers are not just litigators but rather, as Sarat and Scheingold have argued, they are involved in a 'mutually constitutive relationship' with the social, political and legal worlds in which they operate and which they help to create. ${ }^{105}$

\subsection{Conclusion}

Women's rights are seen as human rights, and that's again largely because there have been so many women who have been working in this field who've done a good job of pushing and making sure that it's not an issue that we wait to address when the occupation is over, but that you continually address it while the occupation is ongoing. ${ }^{106}$

\footnotetext{
${ }^{101}$ See Ní Aoláin and Turner above note 36 at 264.

102 Personal interview with cause lawyer, Tunis, Tunisia, 20 June 2014

${ }^{103}$ Personal interview with legal academic and human rights activist, Tel Aviv, Israel, 14 May 2014.

${ }^{104}$ Mazzei Lisa A 'An Impossibly Full Voice' in Jackson Alecia Y and Mazzei Lisa A (eds) Voice in Qualitative Inquiry: Challenging Conventional, Interpretive, and Critical Conceptions in Qualitative Research Routledge London and New York 2009 p 45 at 47-48.

105 Sarat Austin and Scheingold Stuart A 'The Dynamics of Cause Lawyering: Constraints and Opportunities' in Sarat and Scheingold above note 41.

106 Personal interview with Palestinian human rights activist and legal academic, Jerusalem, Israel, 19 May 2014.
} 
Just over a decade ago Posner and Vermeule offered a strong critique of the 'exceptionalist' strain in transitional justice. They argued that much transitional justice scholarship had 'gone wrong' by failing to grasp the connections between ordinary justice and ordinary politics in consolidated democracies and the challenges faced in transitional contexts. ${ }^{107}$ In the context of female cause lawyers, that critique provokes at least two interrelated questions: what if anything is unique or different about the contexts of conflict and transition in terms of shaping the experience of women lawyers? When the 'dust settles' what substantive difference has the contribution of female cause lawyers made (directly or indirectly) to gender equality issues?

We have argued above that what is different about the experience of women lawyers in contexts of conflict and transition is evident in terms of opportunities, the politicisation of lawyering, the intersection of conflict and gender, and the very real personal consequences for engagement in such work. As will be clear from our use of the cause-lawyering and sociology of lawyers' literature, we share the view that those of us who work in transitional justice should remain open to theoretical and practical insights from non-transitional settings. We nonetheless contend that the particular scale, intensity and human consequences of the issues faced by cause-lawyers in authoritarian and conflicted contexts such as Cambodia, Chile, Tunisia, South Africa, Israel and Palestine are an obvious and compelling reason for a discrete focus on transitional justice. Moreover, as we know only too well from our own work in Northern Ireland, in contexts where transitions are so often marked by the scars of our particular past, being able to draw on the themes and experiences from other transitional contexts offers a useful bulwark against parochialism and what Ignatieff (borrowing from Freud) has termed the 'narcissism of minor differences' 108 - factors which inevitably mitigate against successful conflict transformation. Indeed in this research we have sought to avoid what Ní Aoláin has termed the dangers of reifying the 'gender agenda'. ${ }^{109}$ We have thus acknowledged the very different historical, cultural, religious and political structures and contexts within which the causelawyers we interviewed live and work and sought to capture some of the range and complexity of that agency.

With regard to the issue of 'making a difference' to gender equality issues we have noted that the 'opportunities' arising for individual female lawyers during both conflict and transition do not automatically translate into wider material gains for women in the legal profession - or indeed wider society. Certainly in the contexts in which we have been researching, themes such as glass ceilings in the legal profession,

${ }_{107}$ Posner Eric A and Vermeule Adrian 'Transitional Justice as Ordinary Justice' (2004) 117 Harvard Law Review 761. See further Ohlin Jens David 'On the Very Idea of Transitional Justice' (2007) 8(1) Whitehead Journal of Diplomacy and International Relations 51.

${ }^{108}$ Ignatieff Michael The Warrior's Honor: Ethnic War and the Modern Conscience Henry Holt \& Co New York 1998.

${ }^{109}$ Ní Aoláin Fionnuala above note 31 at 4. 
silos of legal practice, patriarchal legal and political cultures, and the strains on personal and familial relations are familiar to women lawyers anywhere. This inevitably raises the spectre of patriarchal state-building in the guise of transitional justice. ${ }^{110}$ The related argument that feminists may have channelled precious energy and resources into resolutely patriarchal legal and political transitional processes was most forcefully made in South Africa. Here, as we have noted, the fact that more than twenty years out from the ending of apartheid deep gender inequalities persist inevitably gave rise to disillusionment. Reflecting on what she considered to be 'missed opportunities' for women in South Africa, a former ANC activist stated:

I think that golden age has gone... I think we lost a lot of opportunities, we lost a lot of ground and we lost a lot of women ... Some of them have become diplomats, others went into the party hierarchy, into government ... you get into the structure and well the structure swallows you. And then that voice is no more, you know, it's not possible to put a foot out again and enter the other platform. So now we don't have those public spaces ... organisations we knew during the apartheid era no longer exist. Local structures are not there anymore and if you're out to mobilise people you need a vehicle to do it, you need a mechanism, and we don't have those mediating mechanisms anymore. So yeah, I think we've lost the momentum on that really. ${ }^{111}$

The suggestion that the 'structure' swallows you up resonates with the arguments developed by Gready and colleagues in relation to the inability of transitional justice to withstand the impact of neo-liberal economics. ${ }^{112}$ It also lends weight to the argument made by Ní Aoláin and others that apparent 'gains' for women can sometimes be viewed in hindsight as 'a wily form of gendered window dressing'. ${ }^{113}$ In the case of our field research, this caused us to question whether female cause lawyers have somehow been complicit in propping up and perpetuating deeply

110 Ní Aoláin and Turner above note 36 at 229; Snyder Jack and Vinjamuri Leslie 'Advocacy and Scholarship in the Study of International War Crime Tribunals and Transitional Justice' (2004) 7 Annual Review of Political Science 354.

${ }^{111}$ Personal interview with legal academic and human rights activist, Johannesburg, South Africa, 13 August 2014.

${ }^{112}$ Gready Paul The Era of Transitional Justice: The Aftermath of the Truth and Reconciliation Commission in South Africa and Beyond Routledge London 2011 p 8. See further McAuliff Pádraig 'Structural Causes of Conflict and the Superficiality of Transition' in Corradetti Claudio, Eisikovits Nir and Volperotondi Jack (eds) Theorizing Transitional Justice Routledge London 2016, 93-109; Dave Whyte 'The Crimes of Neo-Liberal Rule in Occupied Iraq' (2007) 47(2) British Journal of Criminology 177.

${ }^{113}$ Ní Aoláin above note 31 at 11; Katherine M Franke contends that '[i]n different ways, and by different means, rebuilding post conflict societies is almost inevitably a process of re-masculinization. Left untended, this process can take the form, for instance, of reinstalling men as good citizens by and through the ideological redefinition of "women's place", or of formulating new political leadership in the form of a "national father". Franke above note 70 at 824 . 
gendered processes, accommodations and structures. ${ }^{114}$ A number of the women we interviewed certainly adopted a pragmatic 'work the system' approach and essentially 'matched' the contribution of their male counterparts. ${ }^{115}$ Resonating with Scheingold's famous 'myth of rights' critique, ${ }^{116}$ we were also conscious that what Bourdieu referred to as the 'force of law' and the social prominence of some 'celebrity' female cause lawyers could arguably displace resources or attention from other 'grassroots' gender struggles. ${ }^{117}$

Mindful of all of these structural challenges, we have nonetheless been buoyed by the experience of interviewing women cause-lawyers for this study. As noted, research on conflict and transition is sometimes inclined to cast men as active agents and women as largely passive victims. ${ }^{118}$ This study provides a useful corrective to such tendencies. The women that we interviewed had fought hard to assert their agency, whatever the difficult circumstances of their work. As Kirchheimer has argued, in highly politicised contexts, law and legal settings provide a space for contests over political power and, by invoking claims to justice, lawyers inevitably challenge those in power to justify and rationalise existing power relations. ${ }^{119}$ The women we spoke to were and in many cases remain at the very heart of the social and political struggles of their respective societies. O'Rourke has previously argued that, compared to previous eras, women have secured unprecedented 'influence clout and leverage' and thrown down a challenge to feminists to take responsibility and 'ownership of the consequences of our advocacy and participation in transitional justice processes.' 120 Many of the cause lawyers we interviewed have done exactly that.

\footnotetext{
114 More than twenty-five years ago Carol Smart produced a ground-breaking critique of feminist engagements with law. Adopting a post-structural analysis, she argued that law as a discourse inevitably excludes women by failing to account for women's experience and knowledge. Smart Carol Feminism and the Power of Law Routledge London 2011.

${ }^{115}$ Ní Aoláin cautions against 'an emphasis on including women to match off the presence of men' arguing that this may fail to address 'the hierarchies of race, ethnicity, religious affiliation and social status that privilege elite women partly because their biographies look the most like those of the men present and included in transitional processes.' Ní Aoláin above note 31 at 16.

116 Scheingold Stuart The Politics of Rights: Lawyers, Public Policy, and Political Change Yale University Press New Haven 2nd ed 2004.

117 Pierre Bourdieu 'The Force of Law: Towards a Sociology of the Juridical Field' (1987) 38 Hastings Law Journal 805. Manji also argues that, in the African context, lawyers can be viewed as part of a postcolonial bourgeoisie whose intimate bond with the state 'determines the approach taken and means that endeavours to ameliorate the position of women remain within the magnetic field of state law and within the dominant paradigm of legal centralism.' Manji Ambreena S 'Imagining Women's "Legal World": Towards a Feminist Theory of Legal Pluralism in Africa' (1999) 8(4) Social and Legal Studies 440. 118 See for example, Campbell above note 32 at 427.

119 Kirchheimer Otto Political Justice: The Use of Legal Procedure for Political Ends Princeton University Press Princeton 1961 pp 430-431. See also Habermas Jürgen Between Facts and Norms: Contributions to a Discourse Theory of Law and Democracy trans Rehg William Polity Press Oxford 1996.

${ }^{120} \mathrm{O}^{\prime}$ Rourke above note 33 at 248.
} 